\title{
Chromosome studies of males in an institution for the mentally handicapped
}

\author{
C J ENGLISH*, E V DAVISON*, M S BHATE $\dagger$, AND L BARRETT
}

From *the Department of Human Genetics, University of Newcastle upon Tyne; the Department of Psychiatry, Prudhoe Hospital, Northumberland; and $\ddagger$ the Child and Family Psychiatric Unit, Queen Elizabeth Hospital, Gateshead, Newcastle upon Tyne.

SUMMARY Karyotypes were examined in $512(91.9 \%)$ of 557 male patients in an institution for the mentally handicapped. A total of $110(21.5 \%)$ had an abnormal karyotype: $65(12.7 \%)$ with Down's syndrome, $30(5.9 \%)$ with the fragile $X$ syndrome, $13(2 \cdot 5 \%)$ with autosomal anomalies other than Down's syndrome (12 unbalanced, one balanced), and two $(0.4 \%)$ with sex chromosome anomalies.

The prevalence of chromosome anomalies in mentally handicapped male populations has been reported as $11.9 \%$ in north-east Scotland, ${ }^{1}$ with various levels up to $17.6 \%$ in Australia. ${ }^{2}$ These studies were before the importance of the fragile $\mathrm{X}$ syndrome in male mental handicap was established, and subsequent investigations have concentrated on the prevalence of fragile $\mathrm{X}$ males in mentally handicapped populations. ${ }^{3}$ This paper documents the results of a cytogenetic survey ( $G$ banded and fragile $\mathrm{X}$ ) of the male population of Prudhoe Hospital, Northumberland.

At the time of study there were 557 males resident at the institution. In 24 cases permission for cytogenetic investigation was refused by the next of kin and 15 males with a known non-chromosomal cause of their mental handicap were excluded. The diagnoses in these patients were phenylketonuria (4), encephalopathy (4), meningitis (2), surgical complications (2), birth trauma (1), hypoxaemia at birth (1), and haemolytic disease at birth (1). In a further six cases it was impossible to obtain a blood sample. In all, $512(91.9 \%)$ of the patients were studied.

\section{Methods}

Venous blood was cultured for 72 hours in RPMI 1640 medium (Gibco BRL) using standard laboratory techniques, and in Iscove's modified medium (Flow Laboratories) for fragile $\mathrm{X}$ induction. Ethidium bromide (final concentration $1 \mathrm{~g} / \mathrm{l}$ ) was used to

Received for publication 8 July 1988.

Revised version accepted for publication 25 November 1988. produce longer chromosomes. $\mathrm{G}$ banding was by a standard trypsin/Leishman method.

One hundred metaphases were examined for the fragile $\mathrm{X}$ chromosome and $10 \mathrm{G}$ banded metaphases fully analysed from each male for other chromosome anomalies.

\section{Results}

The abnormal karyotypes are listed in table 1 . Of the 512 males, $110(21 \cdot 5 \%)$ were shown to have an abnormal karyotype. There were 66 aneuploid (64 autosomal and two sex chromosome) and 14 structurally abnormal karyotypes. The structural abnormalities comprised one balanced translocation and

TABLE 1 Abnormal karyotypes.

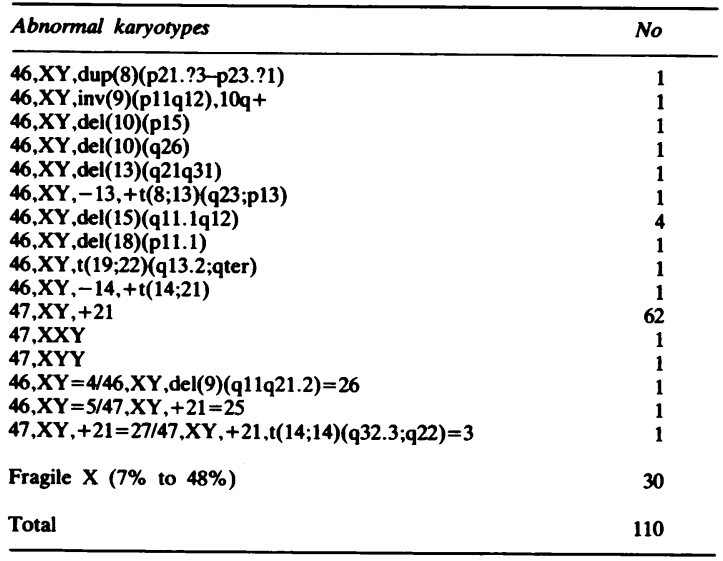


TABLE 2 Cytogenetic surveys of four mentally handicapped populations.

\begin{tabular}{|c|c|c|c|c|c|c|c|c|c|c|c|c|}
\hline \multirow[t]{4}{*}{ Reference } & \multirow{4}{*}{$\begin{array}{l}\text { Population } \\
\text { description }\end{array}$} & \multirow{4}{*}{$\begin{array}{l}\text { No of } \\
\text { males } \\
\text { in } \\
\text { survey }\end{array}$} & \multicolumn{10}{|c|}{ Chromosome abnormality } \\
\hline & & & \multirow{2}{*}{\multicolumn{2}{|c|}{$\begin{array}{l}\text { Sex } \\
\text { chromosome }\end{array}$}} & \multicolumn{4}{|c|}{ Autosomal } & \multirow{2}{*}{\multicolumn{2}{|c|}{ Total }} & \multirow{2}{*}{\multicolumn{2}{|c|}{$\begin{array}{l}\text { Total } \\
\text { (excluding } \\
\text { Down's) }\end{array}$}} \\
\hline & & & & & \multicolumn{2}{|c|}{ Down's } & \multicolumn{2}{|c|}{ Others } & & & & \\
\hline & & & No & $\%$ & No & $\%$ & No & $\%$ & No & $\%$ & No & $\%$ \\
\hline 4 & $\begin{array}{l}<18 \underset{\mathrm{I}}{\mathrm{y}}<50 \\
\text { I }\end{array}$ & 661 & 2 & 0.3 & 88 & $13 \cdot 3$ & 15 & $2 \cdot 3$ & 105 & $15 \cdot 9$ & 17 & $2 \cdot 6$ \\
\hline 2 & $\begin{array}{ll}4-75 & y \\
86 \% & \text { IQ }<51\end{array}$ & 330 & 3 & 0.9 & 49 & $14 \cdot 9$ & 6 & $1 \cdot 8$ & 58 & $17 \cdot 6$ & 9 & $2 \cdot 7$ \\
\hline 1 & $\begin{array}{l}\text { All ages } \\
\text { IQ }<70\end{array}$ & 1565 & 25 & 1.6 & 153 & $9 \cdot 8$ & 8 & $0 \cdot 5$ & 186 & $11 \cdot 9$ & 33 & $2 \cdot 1$ \\
\hline 5 & $\begin{array}{ll}<29 & \text { y } \\
91 \% & \text { IQ }<50\end{array}$ & 284 & 3 & $1 \cdot 1$ & 26 & $9 \cdot 2$ & 9 & $3 \cdot 2$ & 38 & $13 \cdot 4$ & 12 & $4 \cdot 2$ \\
\hline Total & & 2840 & 33 & $1 \cdot 2$ & 316 & $11 \cdot 1$ & 38 & $1 \cdot 3$ & 388 & $13 \cdot 7$ & 71 & $2 \cdot 5$ \\
\hline This study & $\begin{array}{l}15-85 y \\
I Q<70\end{array}$ & 512 & 2 & 0.4 & 65 & $12 \cdot 7$ & 13 & $2 \cdot 5$ & 80 & $15 \cdot 6$ & 15 & 2.9 \\
\hline
\end{tabular}

"Population of Speed et al $^{1}$ resident in institution and at home; all others resident in institution.

TABLE 3 Chromosome abnormalities in males of four mentally handicapped populations.

\begin{tabular}{|c|c|c|c|c|c|c|c|c|c|c|c|c|c|c|c|c|c|}
\hline \multirow[t]{4}{*}{ Reference } & \multirow{4}{*}{$\begin{array}{l}\text { No } \\
\text { in } \\
\text { survey }\end{array}$} & \multicolumn{16}{|c|}{ Chromosome abnormality } \\
\hline & & \multirow{2}{*}{\multicolumn{2}{|c|}{$\begin{array}{l}\text { Sex } \\
\text { chromosome }\end{array}$}} & \multicolumn{6}{|c|}{ Autosomal (non-Down's) } & \multicolumn{8}{|c|}{ Down's syndrome } \\
\hline & & & & \multicolumn{2}{|c|}{ Balanced } & \multicolumn{2}{|c|}{ Unbalanced } & \multicolumn{2}{|c|}{ Total } & \multicolumn{2}{|c|}{ Trisomy 21} & \multicolumn{2}{|c|}{ Trans 21} & \multicolumn{2}{|c|}{$\begin{array}{l}\text { Mosaic } \\
\text { trisomy } 21\end{array}$} & \multicolumn{2}{|c|}{ Total } \\
\hline & & No & $\%$ & No & $\%$ & No & $\%$ & No & $\%$ & No & $\begin{array}{l}\% \text { (of } \\
\text { Down's) }\end{array}$ & No & $\begin{array}{l}\% \text { (of } \\
\text { Down's) }\end{array}$ & No & $\begin{array}{l}\% \text { (of } \\
\text { Down's) }\end{array}$ & No & $\%$ \\
\hline 4 & 661 & 2 & $0 \cdot 3$ & 2 & $0 \cdot 3$ & 13 & $2 \cdot 0$ & 15 & $2 \cdot 3$ & 81 & $92 \cdot 1$ & 6 & 6.8 & 1 & $1 \cdot 1$ & 88 & $13 \cdot 3$ \\
\hline 2 & 330 & 3 & 0.9 & 1 & $0 \cdot 3$ & 5 & $1 \cdot 5$ & 6 & $1 \cdot 8$ & 47 & 95.9 & 1 & $2 \cdot 0$ & 1 & $2 \cdot 0$ & 49 & 14.9 \\
\hline 1 & 1565 & 25 & 1.6 & 0 & 0 & 8 & 0.5 & 8 & 0.5 & 144 & $94 \cdot 1$ & 2 & $1 \cdot 3$ & 7 & $4 \cdot 6$ & 153 & $9 \cdot 8$ \\
\hline 5 & 284 & 3 & $1 \cdot 1$ & 3 & $1 \cdot 1$ & 6 & $2 \cdot 1$ & 9 & $3 \cdot 2$ & 22 & 84.6 & 4 & 15.4 & 0 & 0 & 26 & $9 \cdot 2$ \\
\hline Total & 3036 & 34 & $1 \cdot 1$ & 6 & 0.2 & 32 & $1 \cdot 1$ & 38 & $1 \cdot 3$ & 294 & $93 \cdot 0$ & 13 & $4 \cdot 1$ & 9 & 2.9 & 316 & $11 \cdot 1$ \\
\hline This study & 512 & 2 & 0.4 & 1 & 0.2 & 12 & $2 \cdot 3$ & 13 & $2 \cdot 5$ & 63 & 96.9 & 1 & 1.5 & 1 & $1 \cdot 5$ & 65 & 12.7 \\
\hline
\end{tabular}

13 unbalanced karyotypes (five with extra chromosomal material and eight with deleted material). Of the four males with the $\operatorname{del}(15)(\mathrm{q} 11.1 \mathrm{q} 12)$ karyotype, none showed the classic Prader-Willi symptoms. Thirty males expressed the fragile $\mathrm{X}$ chromosome at levels ranging from $7 \%$ to $48 \%$. All were clinically fragile $X$, with only one patient not showing macro-orchidism. Clinical details on all patients will be discussed in further papers (Davison et $a l$, in preparation; Bhate et al, in preparation).

There have been many cytogenetic investigations of mentally handicapped populations and the results for males in four of these are summarised in tables 2 and 3 together with the results obtained from this study.

\section{Discussion}

The most significant finding in this study was the prevalence of autosomal structural abnormalities, $2.5 \%$ with $2.3 \%$ being unbalanced, which is almost double the $1.3 \%$ found in the other surveys. The most obvious explanation is the use of extended banding techniques. At least six of the unbalanced chromosome anomalies detected were small deletions or extra material which could have been missed using standard $\mathrm{G}$ banding. The population of this institution was examined cytogenetically 16 years ago ${ }^{67}$ using only unbanded chromosome preparations and a frequency of only $1 \%$ of autosomal anomalies other than Down's syndrome was reported. Accepting that over 16 years the population would have changed, and the prognosis for chromosomally abnormal subjects improved, the higher prevalence in our study is still most probably the result of the use of more sophisticated techniques.

The frequency of balanced structural rearrangements $(0.2 \%)$ agrees with the other surveys. Although it is well established that de novo structural rearrangements can have a deleterious phenotypic effect, ${ }^{89}$ it was not possible to determine the origin of our apparently balanced translocation as parental karyotypes were not available. 
The prevalence of fragile $\mathrm{X}$ males was $5.9 \%$ overall and $6.7 \%$ in the non-Down's syndrome population. Published surveys report the frequency varying from $0 \%{ }^{10}$ to $8 \%{ }^{3}$ Our results confirm the findings of others ${ }^{3} 11$ that it is the second largest group of cytogenetically abnormal males in institutions for the mentally handicapped.

The largest cytogenetically abnormal group in our population was Down's syndrome $(12 \cdot 7 \%)$. This frequency is in agreement with the other surveys, which vary from $9 \cdot 2 \%$ to $14.9 \%$. However, our population had a lower proportion of patients with a translocation, $1.5 \%$ as opposed to $4.1 \%$ in the other surveys and $5 \%$ quoted by Giraud and Mattei. ${ }^{13}$ These discrepancies could be accounted for by differences in maternal age distributions.

Frequencies of mosaicism in Down's syndrome patients are reported from $2 \cdot 7 \%{ }^{13}$ to $2 \cdot 9 \%$ (table 3 ). Only $1.5 \%$ of cases in our population had mosaic karyotypes. This may reflect the severity of mental handicap in our institution; the majority of patients have an IQ of less than 50 .

The prevalence of sex chromosome anomalies was $0.4 \%$, compared to $1.2 \%$ in the other surveys. In the general population the prevalence of $47, \mathrm{XXY}$ and $47, X Y Y$ is $0 \cdot 12 \%$ and $0 \cdot 11 \%$, respectively. ${ }^{14}$ Thus, sex chromosome anomalies are only slightly overrepresented in this institution. Again our low prevalence may be a reflection of the severity of handicap of the patients; sex chromosome anomalies are more frequently found with mild mental handicap and behavioural disorders. ${ }^{15}$

With the use of good cytogenetic technology our study has shown that more than one in five subjects in our institution have a chromosomal cause of their mental handicap. As a large majority of these anomalies have implications for other family members, it is crucial that these subjects are identified. All of the disorders we have detected can be diagnosed prenatally and family members at risk of producing a handicapped child should be given the opportunity of prenatal screening. We would therefore recommend cytogenetic screening of institutions for the mentally handicapped using current cytogenetic technology.

Grateful thanks are extended to the patients, their relatives, nursing staff, and Miss D McGinley of Prudhoe Hospital for their cooperation and help; to
Drs Berney and Blessed for helping to initiate the project; Mrs M Gale for assistance throughout; and Professor D F Roberts for criticism of the manuscript. This study was funded by the Northern Regional Health Authority.

\section{References}

1 Speed RM, Johnston AW, Evans HJ. Chromosome survey of total population of mentally subnormal in north-east of Scotland. J Med Genet 1976;13:295-306.

2 Sutherland GR, Murch AR, Gardiner AJ, Carter RF, Wiseman C. Cytogenetic survey of a hospital for the mentally retarded. Hum Genet 1976;34:231-45.

3 Primose DA, El-Matmati R, Boyd E, Gosden C, Newton M. Prevalence of the fragile $\mathrm{X}$ syndrome in an institution for the mentally handicapped. Br J Psychiatry 1986;148:655-7.

${ }^{4}$ Cassiman JJ, Fryns JP, Deroover J, Van Den Berghe H. Sex chromatin and cytogenetic survey of 10417 adult males and 357 children institutionalized in Belgian institutions for mentally retarded patients. Humangenetik 1975;28:43-8.

5 Jacobs PA, Matsuura JS, Mayer M, Newlands, IM. A cytogenetic survey of an institution for the mentally retarded. I. Chromosome abnormalities. Clin Genet 1978;13:37-60.

${ }^{6}$ Newton MS, Jacobs PA, Price WH, Woodcock G, Fraser IA. A chromosome survey of a hospital for the mentally subnormal. Part 1. Sex chromosome abnormalities. Clin Genet 1972;3: 215-25.

7 Newton MS, Cunningham C, Jacobs PA, Price WH, Fraser IA. Chromosome survey of a hospital for the mentally subnormal. Part 2. Autosome abnormalities. Clin Genet 1972;3:226-48.

${ }^{8}$ Breg WR, Miller DA, Allerdice PW, Miller OJ. Identification of translocation chromosomes by quinacrine fluorescence. $\mathrm{Am} \mathrm{J}$ Dis Child 1972;123:561-4.

9 Jacobs PA. Correlation between euploid structural chromosome rearrangements and mental subnormality in humans. Nature 1974;249:164-5.

${ }^{10}$ Kinnell HG, Banu SP. Institutional prevalence of fragile $X$ syndrome. Lancet 1983;ii:1427.

" Blomquist HK, Gustavson KH, Holmgren G, Nordenson I, Palsson-Strae U. Fragile $X$ syndrome in mildly mentally retarded children in a northern Swedish county. A prevalence study. Clin Genet 1983;24:393-8.

12 Gustavson KH, Blomquist HK, Holmgren G. Prevalence of the fragile-X syndrome in mentally retarded boys in a Swedish county. Am J Med Genet 1986;23:581-7.

${ }^{13}$ Giraud F, Mattei JF. Aspects epidemiologiques de la trisomie 21. J Genet Hum 1975;23:1-30.

14 de Grouchy J, Turleau C. Clinical atlas of human chromosomes. 2nd ed. New York: John Wiley, 1984.

is Court Brown WM. Sex chromosome aneuploidy in man and its frequency, with special reference to mental subnormality and criminal behaviour. Int Rev Exp Pathol 1969;7:31-97.

Correspondence to Dr C J English, Department of Human Genetics, University of Newcastle upon Tyne, 19 Claremont Place, Newcastle upon Tyne NE2 4AA. 